KRONIKKEN

\title{
Overklassens usynlighed
}

Af John Westergaard 
$\mathrm{M}$ åske er titlen, jeg har valgt til denne kronik, en smule misvisende, da det jeg gerne vil ind på ikke er, at nutidens overklasse er usynlig. Med 'overklasse' mener jeg indledningsvis og for at sige det kort: en snæver gruppe mennesker, i hvis hænder der er samlet en stor koncentration af materiel magt og materielle privilegier. Ganske vist er den nutidige overklasses magt på mange måder usynlig, som jeg vil forsøge at skitsere senere. Men koncentrationen af privilegier er synlig, og den forherligelse af markedet, som efter min mening reelt har styrket overklassens position i løbet af 80 'erne og 90'erne, har samtidig gjort, at man nu nærmest praler med de ophobede privilegier, hvor man tidligere foretrak at holde disse privilegier diskret tilslørede.

Når min titel alligevel hæfter sig ved 'overklassens' usynlighed, så er det usynligheden inden for det meste af den nutidige sociologi, jeg har i tankerne. De fremherskende betragtningsmåder og problemstillinger i 80'erne og 90'ernes sociologi beskræftiger sig ganske enkelt ikke med fænomenet 'overklasse'. Der er agtværdige undertagelser, også inden for den nu stærkt indskrumpede kreds af sociologer er, som endnu vedkender sig marxistiske tilgange $^{1}$. Men disse undtagelser kan tælles på én hånd, og det er stort set som om sociologien, nu hvor vi nærmer os årtusindskiftet, har mistet interessen for overklassens eksistens, rolle og karakter.

Selvfølgelig kan dette måske siges at være blot endnu et udslag af en aktuel mangel på sociologisk interesse for klassestruktur og klasseforhold i det hele taget. Men helt så simpelt er det nu ikke. De sidste 10-15 års afstandtagen fra klasseanalytiske problemstillinger antager generelt set to former. Dels koncentrerer man sig om andre samfundsmæssige fænomener, eller måske rettere, om samfundsmæssige fænomener, der behandles som om klasseperspektivet var disse uvedkommende. Dels ser vi også direkte klassebenægtende teorier og hypoteser, påstande og spekulationer i den nutidige sociologi. Det siges eksempelvis her, at den generelle levefod nu er nået op på et sådant niveau, at tidligere tiders klasseulighed, hvad angår levevilkår og 'livschancer' ikke længere har nogen modsvarighed i folks bevidsthed. Man siger så videre, at både dette og en samtidig fortsat omlægning af økonomien har frigjort et voksende antal mennesker fra en tidligere livsskæbne bundet til produktionsog arbejdsforholdene. Det fremføres, at der samtidig hermed er skabt en ny valgfrihed og mulighed for at danne sig en personlig identitet uafhængig af klassetilhørsforhold. Det tilføjes så ganske vist, at dette ikke gælder en ny voksende gruppe af marginaliserede - en såkaldt by 'underclass', der enten som følge af et 'kulturel valg' ikke vil 'følge med' eller som følge af den økonomiske organisation ikke kan 'følge med. Det hævdes samtidig at de marginaliserede ikke blot er og forbliver et mindretal, men også at deres situation netop understreger en polarisering, som nota bene, er kommet det store flertal til gode. Diagnosen eller prognosen er altså her, at de gamle klasseskel er under stærk og stadig opløsning. Der gør sig således et væsentligt skel gældende, nemlig mellem de udstødte (eller i en speciel amerikansk tolkning: de uvillige) på den ene side og på den anden side et 'flertalssamfund', der er klasseløst eller stærkt på vej til at være klasseløst.

$\mathrm{Nu}$ vil jeg ikke komme nærmere ind på disse hypoteser i al deres generalitet; heller ikke på at modbevise dem som 

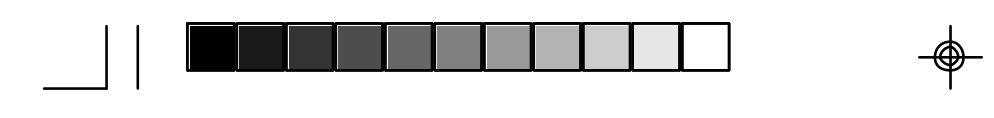

sådan, hvilket jeg har søgt at gøre andetsteds $^{2}$. Det jeg derimod vil fremhæve er tre ting - for det første at der er tale om direkte klassebenægtende teorier, ikke blot om blindhed eller ligegyldighed overfor klassecentrerede problemstillinger; for det andet at disse spekulationer har ført til en sociologisk debat, $i$ al fald i UK i de senere år ${ }^{3}$; og for det tredje at man så vel nok skulle vente, at den debat ville være kommet ind bl.a. på spørgsmålene omkring en overklasse. Skulle de klassebenægtende spekulationer holde stik, så måtte de også forudsætte en opløsning af den koncentration af magt og privilegier på få hænder i samfundstoppen, som efter min opfattelse kan sammenfattes i begrebet overklasse. Med andre ord, har man en overklasse, så har man ipso facto også en decideret klassestruktur, hvilken form den så end måtte antage. Det mærkværdige er da, at debatten - i al fald den britiske debat, igen med ganske få undtagelser - ikke har beskæftiget sig med fænomenet overklasse. Gennemgående har man simpelthen ladet emnet ligge hen sociologisk uberørt.

Dette er efter min mening så meget desto mere mærkværdigt, for så vidt som vi sociologer har været optaget af denne debat før, og da blev fænomenet overklasse netop taget i betragtning. Det var i 50'erne og 60'erne, da klassebenægtende teorier også bredte sig. Men disse teorier holdt sig ikke blot til påstande om arbejderklassens "borgerliggørelse" ("embourgeoisement"), eller om en forvandling af "fattigdom" fra et klassefænomen til en række diskrete, personligt betingede livsrisikoer. Logisk nok indgik der også, og ikke mindst, påstande om overklassens fremadskridende opløsning. Dér hævdede man på denne reviderende fløj, at fordums overklasse-privilegier var ved at forsvinde grundet en reformvenlig statsstyret omfordeling af både kapital og indtægter. Dette blev understøttet af fagforeningerne, som på et voksende arbejdsmarked var i stand til at beskære kapitalprofitten yderligere. Kapitalens bestemmende indflydelse og profit havde fået vingerne stækket netop lig væksten af en velfærdsorienteret stat og den inddragelse af løn arbejder-organisationer i formuleringen af den økonomiske politik, der blev beskrevet som trepartskorporatisme. Det var en beskæring af kapitalens magt der så at sige kom udefra.

Men også inden for det private erhvervlivs egne organisationer, blev der sagt, var den bestemmende indflydelse ved at glide nedefter i de store firmaers hierarkier. Denne tese gik ud på, at efterhånden som aktiebesiddelse blev mere udbredt, kom den reelle styrelse af storkapitalen til at ligge i hænderne hos lønansatte funktionærer - managers - som fulgte en række andre kriterier for driften end blot dette at maksimere profitten. Summa summarum mente man altså, at den tidligere koncentration af magt hos en kapitalstærk overklasse var godt på vej til at blive tæmmet gennem en omfattende pluraliseringsprocess. Selv om al koncentration af magt ikke var ved at blive udvisket, så var der nu tale om diverse magtkoncentrationer i flertal - en pluralitet af forskellige eliter, der repræsenterede forskellige, både egne og bredere interesser, og hvis indbyrdes konkurrence førte til skiftende, men aldrig ensidigt orienterede magtbalancer ${ }^{4}$.

Disse revisionistiske fortolkninger kunne bestrides, ihærdigt og empirisk, og det blev de også. Min hensigt med at omtale dem her er ikke at gå ind på en egentlig vurdering, men blot at minde om, hvordan klassebenægtende teori for en 30 - 40 år siden - helt logisk - tog 
fænomenet overklasse alvorligt. Det gør den nutidige sociologis klassebenægtende teorier derimod ikke. Måske dog et lille skridt i den retning, når det siges, at det nye frit virkende marked har givet reel magt til forbrugerne - såkaldt "consumer empowerment" ${ }^{\text {" }}$. Deraf skulle man vel kunne aflede, at magten er aftaget tilsvarende hos producenterne og kapitalen. Men denne slutning er svær at fastholde med de fortsatte tendenser til konkurrence hæmmende kapitalkoncentration i økonomien; med den svækkelse af lønarbejderorganisationerne, som er fulgt med de større skævheder i indtægtsfordeling, som også hører med til det frit virkende marked. Disse ting vil jeg komme ind på senere. Men inden da vil jeg notere, at selv de sociologer, som nu på postmodernistisk eller højreradikal vis fejrer privatforbrugets blomstring, sjældent om nogensinde endnu har søgt at uddybe deres egne diagnosers konsekvenser for magt-og privilegiesamlingen i samfundets top.

At der er så slående en sociologisk tavshed omkring fænomenet overklasse, kan ses som tegn på den "tidsånd", der også har indflydelse på sociologers interesseprioritering. Blev tavsheden brudt, ville det $\mathrm{i}$ al fald ikke være svært at påvise netop en voksende koncentration af materiel magt og privilegienydelse på samfundstoppen. Når jeg nu søger at gøre dette, omend blot i skitseform, så bliver det med henblik på UK. Var Danmark i søgelyset, ville billedet næppe være helt så skarpt, skønt tendenserne nok er lignende på adskillige punkter. Men dels kender jeg selvfølgelig det britiske stof bedst - og der skal empiri til, og dels står paradokset om 'overklassens usynlighed' for sociologien markant frem netop i UK, hvor kombinationen af magt og privilegier har sat så stort et præg på de senere års sociale udvikling. Paradokset bliver endnu skarpere, når man tænker på, hvor førende en rolle problemstillinger om klasse-og klassemagt tidligere har haft i britisk samfundsforskning.

Lad mig starte med privilegierne. Det er ganske vist at vende om på det sandsynlige årsagsforløb. Privilegier må ses som resultat af magt mere end som grundlag for magt, skønt der en vekselvirkning her imellem. Men empirien er nemmere m.h.t. privilegierne, forsåvidt som man kan tælle og har rimeligt pålidelige tal at støtte sig til. Gør man det først med den senere tids forskydninger i indtægtsfordeling for øje, så finder man, at fra 1979 til 1992, steg den gennemsnitlige real-indkomst med $60 \%$ hos den rigeste tiendedel af UK's befolkning. Til sammenligning faldt real-indkomsten hos den fattigste femtedel, eller den stod nogenlunde stille, afhængigt at hvilke af to beregningsmåder man bruger. For hele befolkningen var den aritmetiske gennemsnitsgevinst noget mere end 30\% i løbet af disse ca. 13 år, men dette tal er misvisende netop pga. gevinstkoncentrationen på de høje niveauer. Godt og vel den halve befolkning tog realgevinster hjem, som lå klækkeligt lavere end pseudo igennemsnittets ca. $30 \%$. Ser man nærmere på nogle af de hovedingredienser, der indgår i den samlede indtægtsfordeling arbejdslønninger og helhedsvirkningen af skattesystemet og de sociale ydelser - viser det samme mønster sig: dvs. store gevinster i toppen, mindre og mindre gevinster når man bevæger sig nedefter; stilstand eller ligefrem tab i bun$\operatorname{den}^{6}$.

$\mathrm{Nu}$ er den rigeste tiendedel af befolkningen, der tog hovedgevinsten på $60 \%$ stigning, for stor og for broget en flok til at kunne betegnes som "overklasse". Men går man fra den officielle og halv-officielle statistik til suppleren- 
de kilder, finder man forventeligt nok, at jo nærmere man kommer toppen, jo større bliver gevinsterne. F.eks. steg gennemsnitslønningerne for direktører i UK's 100 største firmaer reelt med over $100 \%$ på blot ni år frem til $1992^{7}$. Endnu kraftigere stigninger på ganske få år for lederne i nyligt privatiserede vand-, gas- og elkraftvirksomheder har vakt sådant røre, at selv regeringen ( $\mathrm{i}$ 1996) har måttet tale om behov for en smule selv-disciplin hos erhvervsspidserne. Bekræftelse på koncentrationstendenserne får man også, når man ser på den offentlige statistiks beregninger over fordelingen af personligt ejede formuer. På dette område kunne man tænke sig, at voksende selveje af boliger ville have ført til en vis almen dekoncentration. Det var da også tilfældet i 1960'erne og ind i 70'erne; og fra 1979 tog det nye konservative regime netop ihærdigt fat på at sprede selveje af egen bolig. Men den ventede dekoncentration af ejendom generelt set fulgte ikke længere med, tværtimod. Kigger man nærmere på tallene, ser man hvorfor. Ny koncentration af værdier $i$ anden form - dvs. væsenligst i form af aktier, obligationer og lignende værdipapirer - vejede tungere end den større udbredelse af eje af egen bolig. Og ser man bort fra den sidstnævnte kategori, finder man, at kapitalkoncentrationen voksede i årene fra 80'ernes til 90'ernes start: de rigeste $5 \%$ formuer steg da fra $45 \%$ til $53 \%$ af helheden, og de rigeste $1 \%$ formuer alene fra $26 \%$ til $28 \%{ }^{8}$

Når nu blot $1 \%$ af den voksne befolkning sidder inde med godt over en fjerdedel af den samlede værdipapir masse i personlig eje, så begynder man jo at øjne en "overklasse", selvom $1 \%$-skranken jo naturligvis blot kommer fra statistikkens fremstilling. Man begynder også at tangere forhold, som har direkte med magt at gøre, idet koncentreret ka- pitalejendom giver potentiel magt så vel som stor indkomst. Men selv bortset fra det, vil jeg mene, så følger der også visse former for magt i dagligdagen med dette at have store indkomst-privilegier. Der er i første række tale om tilsvarende stor forbrugskraft. Når det nu kan anslås for UK, at de bedst stillede $5 \%$ af befolkningen i disponibel indkomst har lidt mere mellem hænderne end hele den fattigste tredjedel af befolkningen ${ }^{9}$, så må den købekraft i toppen have en del at sige for forbrugermarkedernes udformning; ikke mindst mht. markederne for det Fred Hirsch kaldte "positional goods", hvis værdi består i, at kun få har reel adgang hertil ${ }^{10}$. Dertil kommer, at mange penge normalt giver høj status og gode forbindelser. På sådanne punkter glider nydelsen af privilegier diskret over i udøvelsen af magt og indflydelse. Men lad mig nu komme nærmere og mere direkte ind på spørgsmål om magt. Dette vil jeg gøre ved først at se på kilderne til indkomstprivilegierne.

Spørger vi om, hvor de største indtægter kommer fra, så er svaret, at de gennemgående følger med nøgle-positioner i de netværk, hvorfra det store erhvervslivs styring udgår. Som vi har lært i UK særligt gennem sociologen John Scotts mangeårige arbejde - Scott er en fin undtagelse fra sædvanen om at se bort fra overklassefænomenet ${ }^{11}$ så er der her tale om ret komplekse netværk mellem bestyrelserne for store firmaer, banker og andre finansinstitutioner (deriblandt også pensionskasser) og dertil forskellige konsulentvirksomheder. Der er tale om en udøvelse af strategisk magt - altså magt knyttet til beslutninger om investeringer, "rationalisering", markedernes udformning i en blanding af konkurrence og oligopol samforståelse osv. - hvori indgår aktiebeholdninger og adgang til kredit i me- 
get større omfang, end selv de rigeste enkeltpersoner eller familiegrupper normalt har til rådighed. I UK's storkoncerner, f.eks., ligger nu de store aktieandele meget mere i hænderne hos andre firmaer, pengeinstitutioner og pensionsfondes end hos individer og slægtskabsgrupper. Beslutningsprocesserne, udøvelsen af magt og afgørelserne $\mathrm{i}$ indbyrdes konfliktsituationer kan derfor beskrives som "anonyme" processer. Men dog står der jo mennesker bag; og de mennesker, som sidder i netværkene og nøglestillingerne, er ikke blot rige i kraft af klækkelige direktørlønninger, konsulent-honorarer, udgiftskonti og nok så pæne personlige aktie-beholdninger. Indenfor små kredse har de andel i styrelsen af korporative kapitalværdier, der mange gange overstiger den rigdom, de hver for sig eller endog samlet har stående på egne konto.

Det er et magtkompleks, men ikke noget magtkomplot, jeg her beskriver. Netværksforbindelserne inden for storkapitalen har ligesom kapitalkoncentrationen og oligopolet udviklet sig, om ikke "naturligt" så da "naturnødvendigt", for at begrænse den konkurrence, der stadig pågår. De stærkeste netværksforbindelser er dem, som går udover nationale grænser og er godt $i$ færd med at danne en international topkapitalklasse. Der ligger ikke noget principielt nyt i min skitse, selv ikke m.h.t. dette sidste fænomen, der har været under udvikling gennem adskillige årtier. Det nye for de sidste ca. 15 års vedkommende, og i al fald for UK's vedkommende, stammer groft sagt fra trepartskorporatismens opløsning. Ganske vist har virkningerne her af ikke været helt entydige. En af statens roller i 1960'erne og 70'ernens korporatisme var at formidle en vis koordinering af økonomisk planlægning og investering både m.h.t. offentlig "infrastruktur" og hvad angår den private sektor. Det gjaldt, selvom den korporatistiske koordinering syntes en del mindre effektiv i UK, end den på nogenlunde samme tid har været $\mathrm{i}$ Frankrig, hvis model britisk politik søgte at følge. Nu har den britiske regerings afsværgelse af korporatismen så betydet, at den slags koordinering fra 1980'erne og fremefter foregår på mindre konsekvent måde, den afhænger mest af de interne kapitalnetværk uden åbenbar eller aktiv statsformidling, og den har netop stærkt forsømt den offentlige infrastruktur. Alt dette kan siges at have understreget en mangeårig tendens $\mathrm{i}$ den britiske erhvervsverden til at søge profit på kortsigtet basis snarere end med henblik på overlevelse og styrke på længere sigt. Igen er der næppe tale om et kapitalistisk "magtkomplot" - i al fald ikke et som er dygtigt udført.

Men det andet træk ved korporatismen var jo dens "tredje part", altså inddragelsen af arbejderbevægelsen i formulering af både den økonomiske og hermed også den sociale politik omend, som i praksis i UK, med særligt øje for at holde ro på arbejdsmarkedet. Det $\mathrm{i}$ særdeleshed er nu næsten helt faldet bort siden regimeskiftet $i 1979$ - dels fordi konjunktur-og erhvervsstruktursforvandlingerne markant har svækket fagforbundene og jævne lønmodtagere på arbejdsmarkedet; dels fordi regeringen ganske bevidst har udelukket forbundene fra deltagelse i politikkens tilrettelæggelse og udførelse. Detaljerne, m.h.t. f.eks. forhandlings- og arbejdsvilkår, arbejdskårbeskyttelse samt strejkemuligheder, må jeg lade ligge ${ }^{12}$. Men det gennemgående resultat er helt klart en yderligere magtforskydning til fordel for det private erhvervsliv i almindelighed og toppen heraf i særdeleshed. Her kan man rimeligvis tale om en vis genkonstituering af korporatismen - dvs. 


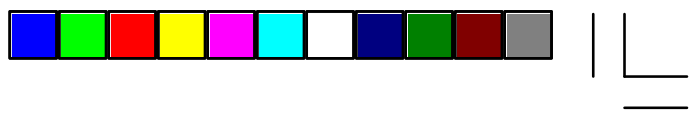

nu en korporatisme uden organiseret arbejderdeltagelse, men hvor private erhvervsledere til gengæld er så meget oftere og tættere "akkrediterede" som "tillidsfolk" for den reelt offentlige politiks tilrettelæggelse og udførelse.

Selve privatiseringsprocessen er et af udtrykkene herfor. Denne proces behøver jeg næppe at komme ind på i detaljer, men skal blot notere, at den har overført store dele af tidligere offentlig virksomhed til privatkapitalistisk foretagsomhed omend for det meste med en form for statsforanstaltet "regulering", som dog primært følger markedsforskrifter for erhvervsdriften. Men man ser også en slags skjult privatisering, hvor det gælder virksomheder, som stadig formelt hører hjemme under den offentlige sektor. I sundhedsvæsenet, f.eks., ligger bestyrelsen nu hos nye organer - National Health Trusts hvor flertallet af ministerudnævnte formænd er forretningsfolk, hovedsagelig direktører. Ansvaret for praktisk orienteret efterskoleuddannelse er blevet lagt i hænderne hos nye, også ministerudnævnte, Training and Enterprise Councils, hvis bestyrelser ved officiel forordning skal bestå for to-tredjedeles vedkommende af erhvervschefer. Ledelsen af større byfornyelsesprojekter overgik allerede for adskillige år siden fra lokale planlægningsmyndigheder til det private erhversliv. Dette sidste er kun et blandt en række foranstaltninger, som siden 1979 drastisk har beskåret kommune- og grevskabsrådenes beføjelser - dels fordi bykommunerne har haft den dårlige (og voksende) vane at indvælge labour eller undertiden liberal-demokratiske flertal - for så at overføre beføjelserne enten til centralregeringen eller til ikke demokratisk valgte organer (såkaldte "quangos"), hvis antal er steget stærkt trods oprindelige regeringsløfter om formindskelse ${ }^{13}$.
"Quangoernes" stigende antal, og den tiltagende rekruttering af deres ledere fra forretningsverden, er konkrete tegn på netop det private erhvervslivs voksende indflydelse på forhold, som formelt set hører hjemme i den offentlig sektor. Mindre konkret, men nok så væsentlig, er den forvandling som er sket - mest fra 1980'erne, men begyndende allerede før regimeskiftet i 1979, - hvad angår kriterierne for den offentlige forvaltnings tilrettelæggelse. Meget mere end før prioriteres nu for "omkostningseffektivitet" på kort sigt. Det kan så være godt, skidt eller en blanding af begge dele. Men der ligger under alle omstændigheder deri en udbredelse af noget, der ligner profitværdier, og som på denne facon afspejler erhvervslivets voksende indflydelse - også i skoler og ikke mindst på universiteter ${ }^{14}$. I denne forbindelse har der samtidigt været rivende vækst i offentlige institutioners ansættelse af "managers" og deres anvendelse af "management consultants", hvis bogholderi-orientering slår tonen an for institutionernes drift. Rammerne omkring afgørelser i den offentlige forvaltning er således flyttet "til højre", knyttet til det private erhvervslivs perspektiver og interesser.

Jeg beskrev for lidt siden disse forvandlingsprocesser som en slags, omend dårlig gennemført, rekonstituering af korporatismen - i en form der ikke længere er tresidig, men nu kun tosidig, med stat og det private erhvervsliv i gensidigt partnerskab, efter et mønster man delvis kan genkende i en mere effektiv og langsigtet form fra nutidens Japan, selvom det utvivlsomt er en grov analogi ${ }^{15}$. Men eet væsentlig fællestræk er der i al fald mellem de to lande - tæt, uformel, men vedvarende kontakt mellem eliterne i henholdsvis det private erhvervssliv og staten. I Japan er denne kontakt velkendt og tages som helt selv- 
følgelig. I UK er den foreløbig mere skjult, og stemmer ikke overens med en tradition, som har lagt vægt på statens formelle uafhængighed. Men hvor tæt kontakten nu er, har man set glimt af i et mindre antal skandaler i de senere år.

Een sådan affære drejede sig om brugen af britisk U-landshjælp til finansiering af en dæmning i Malaysia (Pergau dæmningen) til gengæld for både britisk byggeri af dæmningen og malaysiske våbenbestillinger hos UK fabrikanter.

En anden affære drejede sig om betalinger til Westminster parlamentsmedlemmer - næsten udelukkende konservative - til gengæld for konsulentvirksomhed og fremskaffelse af adgang til ministre og ministerier. Modsat Pergausagen blev røret om disse forbindelser stort nok til, at regeringen oprettede et dommerledet, uafhængigt udvalg til at se her på; og ved frafald fra egen side blev regeringen såmænd nedstemt $i$ Underhuset, omend med nød og næppe, da den gik imod Nolanudvalgets ellers ret moderate forslag til begrænsning eller i al fald klarere offentliggørelse af parlamentsmedlemmers kommercielle forbindelser.

Den tredje og største sag er, efter en stor undersøgelse ved Lord Justice Scott, 1996 afsluttet med en regeringssejr på blot én stemme i Underhuset. Den opstod omkring ministeriel tilladelse og endda påskyndelse til eksport af britisk fabrikeret militært materiale til Irak i tiden før Golf-krigen.

I alle tre tilfælde stod der blæst omkring sagen. Der var alle tre gange tale om bevidst forstillelse over for parlamentet og offentligheden; i Pergausagen om regeringsbrud på reglerne om anvendelse af U-landshjælp; i sag nr. 2 bl.a. om privat aflønning af parlamentsmedlemmer for at stille spørgsmål i Un- derhuset; i Irak-krigsmaterialesagen om brud både på daværende anerkendte regler for våbeneksport og misbrug af forholdsregler til hemmeligholdelse af offentlige forvaltningsprocesser over for en hertil koblet anklage mod nogle af våbenfabrikanterne. Men det er ikke det sensationelle og skandalemæssige, som jeg vil hæfte mig ved her. Selvom det var det der gjorde at sagerne kom frem i lyset, dokumenterede sagerne et meget større omfang af rent rutinemæssige netværksforbindelser - normalt uden klang af "korruption" i sensationel forstand - mellem erhvervslivets, regeringspartiets og i nogen grad også centraladministrationens topfolk ${ }^{16}$. Fra et klasseanalytisk synspunkt, som fokuserer særligt på overklassefænomenet, er det netop sådanne rutinemæssige og normalt lidet synlige forbindelser og samforståelser, der vejer tungt.

Samlet peger alt dette hen på det private erhverslivs hegemoni, som er endnu mere fremtrædende end før. I praksis er det det store erhvervslivs interesser, som er væsentligst forstærket derved, trods den retoriske kælen for det mindre erhvervsliv, der spillede en sekundær rolle i forbindelse med Thatcherismen. Og inden for det store erhvervsliv - forsåvidt som kapitalforbindelsesnetværkene ikke hindrer sådanne sondringer - så er det finans- og serviceerhvervene, der har draget større fordel end den kriseramte producerende industri, skønt man måske nu i topkredse er ved at få øjnene lidt op for, at industriens hårde medfart er gået over gevind og har givet profitmæssigt bagslag. I al fald har den større udbredelse af forretningsverdenens hegemoni i første række betydet en bonus for storkapitalen og dens finansstyrende kredse i City of London. Det er i og omkring de kredse, at den koncentration af materiel magt og privilegier findes, som dan- 
ner grundlag for overklassen.

Denne overklasse udgøres af en ganske lille gruppe og kan næppe afgrænses helt præcist. Efter snævre definitioner er den blevet anslået til blot nogle få promille af befolkningen - mindre endnu end f.eks. den ene procent, som ifølge officiel statistik sidder inde med $28 \%$ af den samlede ejendomsværdi i form af personligt ejet kapital udover boligejendom ${ }^{17}$. Men selvom man sætter grænserne for overklassen lidt mere elastisk, så udgør den næppe mere end et par procent af befolkningen.

Uanset den nøjagtige afgrænsning er der tale om en snævert rekrutteret gruppe, først via uddannelse på en af de skoler, som kaldes "public" men som i realiteten er private, og dernæst via videregående uddannelse på Oxford eller Cambridge Universitet. Overklassens minutiøse omfang; den høje grad af selvrekruttering fra en generation til den næste; de interne slægtskabsforbindelser, som følger med; og den særprægede subkultur, der har sine rødder i alt dette (hvori indgår en formidabel selvsikkerhed, som i England får støtte netop fra privatskole - og Oxbridge opvækstmiljøerne) - giver grundlag for en samhørighed, der kommer ganske "af sig selv" og ikke har de vanskeligheder at overvinde, som både historisk og nutildags vanskeliggør "solidaritetsdannelse" blandt jævne lønmodtagere. Lægger man hertil bestyrelsesnetværkene inden for det store erhvervsliv, fremkommer der et billede af en overklasse, der giver en god del af forklaringen på, hvorfor de interessemodsætninger, man ellers logisk kunne forvente mellem divergerende erhvervskonstellationer - f.eks. i UK mellem "industrikapital" og "finanskapital" - ret sjældent kommer aktivt til syne på topplan. Man tilstræber sig en forsoning uden åben, ja oftest måske uden bevidst, kon- flikt mellem modstridende projekter; selv når kursen lægges ret brat om, som da det radikale projekt om det frit virkende marked kom på dagsordenen i $1970{ }^{\prime}$ erne $^{18}$.

Dette at overklassen er ganske lille undskylder ikke den nutidige sociologis forsømmelse af emnet. Det er jo netop karakteristisk for enhver overklasse, at den er lille. Det er præcist det, der ligger i den koncentration - man må sige den både samfundsformende og samfundsbegrænsende koncentration - af magt og privilegier, som udgør overklassefænomenet. Der er intet "postmoderne" ved alt dette; og det jeg har søgt at beskrive m.h.t. de senere års udvikling skal ikke ses som nogen samfundsstrukturel kovending. Selv trepartskorporatismen gik jo ikke ud på - og går heller ikke i Danmark udpå, hvor meget af den vel stadig findes, - at afskrive kapitalprofittens hovedrolle i økonomiens drift. Grundlaget for en kapitalcentreret overklasse eksisterer derfor fortsat, som et vedvarende "moderne", og slet ikke postmoderne, fænomen. Det nye, i al fald i UK, er blot de færre hæmninger, der nu står i vejen for overklassens hegemoni. Hvad der så er af postmodernitet ved dette, er måske problematikkens usynlighed i det meste af den gængse sociologi, desværre.

\section{Noter}

1. John Scott, hvis arbejde om magtforholdene i og omkring storkapitalistisk virksomhed og om den britiske overklasse, jeg omtaler senere (f.eks. hans Capitalist property and Financial power, Wheatsheaf, 1986 og Who Rules Britian?, Polity Press, 1991), er en særligt bemærkelsesværdig undtagelse indenfor sociologien $\mathrm{I}$ UK. Mens han trækker godt på marxismen, er hans tilgang til sociallagdelingsanalyse som helhed dog bygget på et weberiansk grundlag, som det vil ses i hans Stratification and Power, Polity Press, 1996.

2. J.H. Westergaard, Who Gets What? Polity Press, 1995. Nærværende indlæg trækker sær- 
ligt på kapitel 8 i denne bog.

3. Et symposium som samler en række bidrag til denne debat, findes i: D. Lee og B. Turner (red.), Conflicts about Class , Longman, 1996.

4. I UK var den mest sammenhængende og bestikkende analyse af kapital- og overklassemagtens påståede tilbagegang nok C.A.R. Crosland, The Future of Socialism, Cape, 1956. Skønt bogens tese fik indpas i megen af tidens sociologi, var Crosland ikke sociolog men en fremtrædende Labour politiker; og i forsimplet udgave blev mange af hans argumenter taget op i en serie programpjecer, som Labourpartiet udgav på dette tidspunkt med en moderat reformlinie for øje. De pluralistiske tilgange til beskrivelse og fortolkning af magtforhold, som på nogenlunde samme tid blev koblet med i påstande om overklassens opløsning, blev forfægtet stærkest af amerikanske politiske sociologer, f.eks. R.A. Dahl (bl.a. dennes Pluralist Democracy in the United States, Rand McNally, 1967), men fik også stor indflydelse andetsteds. Derimod bygger min fremstilling her, omend indirekte, på den kritik af pluralistiske tilgange, som klarest eksemplificeres af S. Lukes, Power, Macmillan, 1974.

5. Se f.eks. P. Saunders og C. Harris, "Privatisation and the consumer", Sociology, Februar, 1990

6. Denne skitse af indtægtsforskydningerne i 1980/90ernes UK benytter sig af forskellige analyser af officielt indsamlede datasæt, deriblandt: Department of Social Security, Households below Average Income, 1994, suppleret ved et ministerielt svar på spørgsmål i Underhuset angående højere indtægter; A. Goodman og S. Webb, The Distribution of UK Household Expenditure, 1995, og P. Johnson og G. Stark, Taation and Social Security 1979-89, 1989, begge rapporter fra the Institute for Fiscal Studies; samt egne beregninger fra materiale i de officielle New Earnings Survey rapporter.

7. Se Commission on Social Justice, The Justice Gap, Institute for Public Policy Research, 1993. Spredte oplysninger om indtægter på høje niveauer kommer også frem nu og da i officielle publikationer, f.eks. i serien Reports on top Salaries.

8. Central Statistical Office, Social Trends, 1992. I øvrigt ved man fra tidligere særundersøgelser, at denne koncentration af ejendomsværdier ganske overvejende er klassebestemt og ikke væsentligt alders- og kønsbestemt.
9. Egne beregninger på grundlag af oplysninger i Central Statistical Office, Social Trends, 1989 (tabel 5.11)

10. F. Hirsch, Social Limits to Growth , Routledge \& Kegan Paul, 1977

11. Se J.P. Scott, op.cit. 1986 og 1991, som anført i note 1.

12. Om forskydninger i forholdene mellem arbejdsgivere, fagforbund og lønansatte, se f.eks. R. Martin, Bargaining Power, ClarendonPress, 1992 og en række studier om Workplace Industrial Relations ved M. Millward, N. Stevens m.fl., Dartsmouth Publishing Company.

13. S. Weir og W. Hall (red.), Ego Trip, Democratic Audit, 1994, er et første led i en kortlægning af "quangos" (quasi-autonomous non-governmental organisations)

14. Jeg er kommet lidt ind på disse forholds indvirken på universitetslivet i en forelæsning om "Højreradikale spændinger i britisk universitetspolitik", Sociologisk Instituts Rapportserie, nr. 1, 1995.

15. Se f.eks. K. van Wolferen, The Enigma of Japanese Power, Macmillan/Papermac, 1989 1990.

16. Lord Justice (Sir Richard) Scotts rapport om affæren angående leveringer af militært materiale til Irak udkom 16. februar 1996. Den bliver utvivlsomt en rig kilde til forståelse af regeringsprocesserne i UK, særlig under Thatchers statsministerskab. Men den umiddelbare virkning af rapportens kritik hæmmedes dels af dens format (ca. 1700 sider uden nogen som helst opsummering), dels af en modkampagne angående fortolkningen heraf, som regeringen satte i gang endnu inden offentliggørelsen. Disse ting, samt den taktiske situation i parlamentet, begrænsede frafaldet fra regeringen, sådan at denne vandt Underhusdebatten den 28. februar 1996 med 320 stemmer imod 319. I forbindelse med disse tre store affærer og en del andre, hvor spørgsmål om kommerciel udnyttelse af offentlig forvaltning er kommet på tale i de senere år, giver J . Cook, The Sleaze File, Bloomsbury, 1995, en ganske nyttig omend begrænset oversigt.

17. Disse anslag findes i W.G. Runciman, "How many classes are there in contemporary British society?" Sociology, vol. 24, 1990; og J.P. Scott op.cit., 1991, se note 1.

18. Om overklassens rekuttering og dertil knyttede kulturelle karaktertræk vides, for 
UK's vedkommende, en del fra særundersøgelser i og omkring 1960'erne, men kun lidet siden. Dog viser en formodning om, at det konservative partis parlamentariske ledelse nu rekrutteres på en bredere basis over de senere årtier, sig ikke at holde stik som nogen klar tendens - se D. Baker m.fl., "The Conservative parliamentary elite 1964-1994", Sociology, November 1995; ligesom det ikke har været muligt at påvise direkte sammenhænge mellem politisk elitekomposition og skift i politikkens orientering, f.eks. mellem Thatcherismens gennembrud og en formodet (men altså ikke reelt bevist) større repræsentation af folk fra det mindre erhvervsliv blandt konservative ministre og parlamentsmedlemmer. Det var snarere det ideologiske klima i topkredsene som helhed, der slog om i 1970'erne til fordel for frimarkedsprojektet. Kommentatorer har også i de sidste år talt om, hvorvidt dommerstanden har stillet sig i opposition til den højreradikale regerings centraliseringspolitik, hvilket da ville tyde på en ny splittelse indenfor "the establishment". Disse spekulationer kan ikke ganske afvises og falder i tråd med andre forventelige tegn på en vis strid mellem højprofessionelle gruppers interesser og autonomi på den ene side og frimarkedspolitikkens ideal om monopolbekæmpelse på den anden. Men generelt har forsoninger på topplan dæmpet en sådan strid og m.h.t. dommerstandens muligt voksende skespis overfor regeringsmagten foreligger der endnu ingen systematisk gennemført dokumentation. 